\section{Geoffrey William Myers}

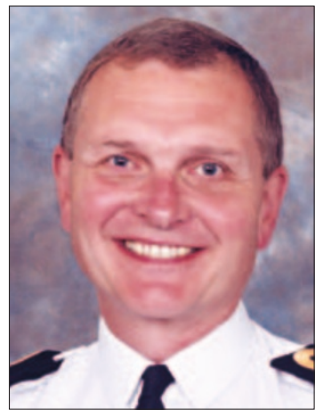

Surgeon Commodore (D) Geoffrey William Myers, the Director Naval Dental Services, died in a road traffic accident on Sunday 17 October 2004, aged 57.

He was born near Rotherham in Yorkshire on 14 June 1947. As a boy he was a member and leader of his church choir and altar server for eight years. He was also a boy scout and senior scout. He attended Leeds Grammar School where he was awarded the Ada Emmor Exhibition before entering Leeds Dental School in 1965. He was granted a Royal Navy cadetship in 1968 and became a Surgeon Lieutenant (D) in 1970.

His early career included time at sea in HMS BULWARK and a variety of shore clinics at home and abroad. In 1980 he attended the Eastman Dental Institute and gained an MSc in Conservative Dentistry. During the Falkland Islands crisis his welfare work with the families of the bereaved and injured was recognised by a Flag Officer Commendation. Following a two-year exchange appointment with the United States Navy Dental Corps, based in Norfolk, Virginia, he moved to Scotland as Senior Dental Surgeon HMS COCHRANE. In 1989 he became the first Royal Navy dentist to attend the Joint Service Defence College at Greenwich. An appointment to Commander-in-Chief Fleet's Headquarters as Deputy Fleet Medical Officer followed, just four months before the 1990 Iraqi invasion of Kuwait. During the first Gulf War he was involved in the establishment of the Primary Casualty Receiving Ship, RFA ARGUS, and for ensuring that the medical and dental organisation was able to support the deployed Royal Navy and Royal Marine units. This work was recognised by the award of the OBE.

He participated in the creation of the Defence Dental Agency in 1996, subsequently holding the posts of Deputy Director Plans and Resources and Deputy Director Clinical Services within that Agency.

\section{John Kay Williams}

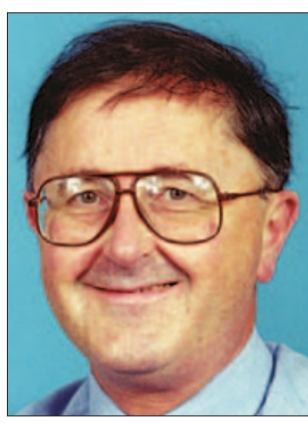

John Williams, Consultant Orthodontist to Pinderfields Hospital in Wakefield and Leeds Dental Hospital, had nearly completed his term as President of the British Orthodontic Society at the time of his sudden death on 3 September 2004. The presidency is the highest honour the Society can bestow on a member, and one that John richly deserved and characteristically performed with all the zeal he brought to everything he did.

In the early 1990s John, with others, made a very great contribution to the unification of the five UK national orthodontic societies which existed at the time - leading to the founding of the British Orthodontic Society in 1994.

He was elected to the Board of the Faculty of Dental Surgery of the Royal College of Surgeons of England in 1989, serving the maximum period allowed, 14 years, and was elected Vice Dean in 1995-96. He was an examiner for the MOrth for many years.

John was born on 7 May 1940 in Leicester. His father was a dentist in the School Dental Service and his mother a primary school teacher. He attended Wyggeston Grammar School in Leicester and qualified BDS at the Royal Dental Hospital of London, School of Dental Surgery in 1962. He passed the DOrth

\section{Above all Geoff was loyal, to the Service, his colleagues and his friends.}

In 2001 he became Director Royal Naval Dental Services in the rank of Surgeon Commodore and was appointed QHDS later that year. His most recent role was as Director Policy and Plans and Chief of Staff at the Defence Dental Agency Headquarters.

The day before his death he was elected an Honorary Fellow of the Faculty of General Dental Practitioners, which he served as a Board member.

Listing his career achievements does not give a full picture of the man. Geoff was a Yorkshireman and proud of the fact. During his time in the sixth form he was drummer and later lead singer in a locally successful rock band. Rock music was a lifelong passion, regularly demonstrated by his virtuoso performances on the dance floor. Above all Geoff was loyal, to the Service, his colleagues and his friends; a quality he combined with a caring attitude and a strong record of public service. He was devoted to his family and was immeasurably proud of his children's achievements. His boundless energy and commitment to all that he undertook was his hallmark. He was a generous and entertaining host; none of his many friends will forget Geoff disappearing into a cold winter's night to cook the evening's main course on his barbecue. His hobbies included furniture restoration, gardening and wine collection. However, much of his spare time was spent on the touchline or around the cricket oval, supporting his children.

Geoff's many colleagues and friends will wish to extend their heart-felt sympathies to his wife Denise, their sons, William and Simon and Geoff's daughter Samantha.

doi: $10.1038 / \mathrm{sj}$.bdj. 4812048

\section{John was an expert clinician ... with an extraordinarily enquiring mind.}

and FDS in 1966 and the MOrth in 1988.

John was an expert and very productive clinician. His students and trainees greatly admired his very practical approach to clinical problems. He was the co-author of two popular orthodontic textbooks. He was part of a team which regularly lectured, gave handson courses in the Far East and was a visiting lecturer in Libya and visiting examiner in Sri Lanka.

John had the knack of making friends easily and was extremely generous with his time in helping them. In particular he loved machines and anything mechanical and was much in demand by his friends to mend anything from watches to cars.

He had an extraordinarily enquiring mind and delighted in posing conundrums to his friends. He had a very wry sense of humour and would have enjoyed the great amusement we shared when some of his wonderfully funny spoof letters from the past were read out at his memorial service.

John is survived by his wife, Sonia and two children.

C.J.R. Kettler, B.G.N. Smith doi: $10.1038 /$ sj.bdj.4812049 